\title{
DEMONSTRATION OF ANTIBODY TO BOVINE LEUKOSIS VIRUS IN MILK BY THE ELISA TEST
}

\author{
B. HOFIREK and MARTA GRANÁTOVÁ ${ }^{+}$
}

\begin{abstract}
Department of Diagnostics, Therapy and Control of Animal Diseases, University of Veterinary Science, 61242 Brno, +Veterinary Research Institute, 62132 Brno
\end{abstract}

Received January 8, 1988

$A$ b s $t r a c t$

Hof irek B., Marta Gra ná $t \circ v a ́$ : Demonstration of Antibody to Bovine Leukosis Virus by the ELISA Test. Acta vet. Brno, 57, 1988: 133-146.

The ELISA test and the immunodiffusion test were compared for their suitability to detect antibody to bovine leukosis virus (BVL) in milk of dairy cows. Sensitivity of the immunodiffusion test in the determination of BLV antibodies in milk proved to be low: positive response was obtained only in $37.7 \%$ of the dairy cows in which the respective serum antibodies were demonstrated. On the other hand, the ELISA method employed under the same conditions, yielded 96.3-100\% identical results in serum and milk. A highly positive correlation between the antibody titre in milk and serum was demonstrated. The antibody titre in milk compared with that in serum was approximately 25. times lower. It is concluded that the determination of BVL antibodies in cow's milk is a suitable method of detection of leukosis reagents.

Enzootic bovine leukosis, antibody, serum, milk.

A widespread survey of enzootic bovine leukosis (EBL) incidence carried out in Czechoslovakia in the years 1982-1984 yielded a fairly good overview as to the infection of herds with this serious disease and enabled to set up a program of eradication ( $B$ e $n d$ a 1984). Eradication of EBL in foci of its occurrence is based upon timely identification of serologically positively reacting animals and their immediate culling. Therefore, two serological methods, immunodiffusion (ID) and ELISA tests have been introduced into the routine practice along with other tests. Results obtained by these methods in the EBL eradication in large-scale cattle operations ( $\mathrm{H} \circ \mathrm{f} \mathbf{i} \mathrm{e} \mathrm{k}$ et al. 1985) were published; repeated serological examination and elimination of the reagents proved to be an effective control measure.

The demonstration of BLV antibodies is usually carried out in serum of examined animals. However, in the eradication program these blood samplings represent $a$ hard and dangerous labour. Furthermore, blood is a potential source of infection and contamination of the environment especially during mass blood sampling. Therefore, less hazardous surveillance methods have been looked for, e.g. antibody detection in cow $s$ milk: ( A 1 t a $n$ e r 
et al. 1982; $\mathrm{T} \circ \mathrm{m}$ a et al. 1984; $\mathrm{Z}$ a $\mathrm{j}$ a $\mathrm{c}$ et al. 1984; $\mathrm{F} \mathrm{r}$ a $\mathrm{n} \mathrm{c}$ et a1. 1984).

In this work, detection of BLV antibodies in milk was attempted with particular attention paid to comparison of the ELISA and immunodiffusion test sensitivities. Using the ELISA method we also compared the onset of antibody production induced by experimental and natural contact infection, the phase of lactation and milk yield being taken into consideration as we11. The final aim of our study was to evaluate the reliability of BLV antibody detection in milk from the viewpoint of routine diagnosis and eradication of EBL in its occurrence foci.

Materials and Methods

In a herd infected with EBL for a long time we examined 87 dairy cows, 45 out of them showing a positive reaction when tested for specific BLV antibodies. Three serological methods were used: serum neutralization test (PsNT), ( $\mathrm{Z}$ á $\mathrm{v}$ a d a et al. 1978), ELISA test and immunodiffusion test (ID) :

Milk samples of the 45 positive animals were examined first by the ID test, antibodies to BLV being determined in fresh milk, in whey obtained by artificial coagulation by Lactochym and in whey obtained by natural coagulation of milk.

In the second experiment in the same group of 45 cows a parallel examination of serum and milk by the ELISA method was carried out and simultaneously the titre of BLV antibodies was determined. The procedure was repeated using the ID test.

Fourteen animals of this herd (they were housed together in a smaller cow-house) were selected for repeated examination for the presence of antibodies to BLV in serum and milk. These animals were also examined by repeated serum neutralization test. Out of them 8 were positive (Table 5) and 6 negative (Table 7) ( 3 of them were infected experimentally. by i.p. inoculation of $1 \mathrm{ml}$ of blood of a virus-positive donor). The remaining three cows were negative and used as controls, being, however, in contact with positive and experimentally infected animals. The interval of examination ranged from 7 to 14 days, the entire experimental period lasted 67 days. A total of 122 parallel milk and blood samples were taken from the 14 animals.

The immunodiffusion test was carried out in agarose gel using a micromethod. A commercial antigen Agebion (Bioveta, Nitra, CSSR) was used. The indirect immunoperoxidase test ELISA was carried out using the ELISA sets for diagnosis of EBL (Bioveta, Ivanovice na Hané, CSSR). The results were evaluated spectrophotometrically on a Titertek Multiscan apparatus. For the serum neutralization test (PsNT) the pseudotype virus of vesicular stomatitis and virus of bovine leukosis was used ( $\mathrm{Z}$ á $\mathrm{v}$ a d a et a1. 1978). The virus detection in the donor whose lymphocytes were used for experimental infection was carried out using the syncytial test (F e r e r and D i 1 i o 1976).

\section{Results}

In the first part of our work, suitability of the ID test for detection of antibodies to $\mathrm{BLV}$ in cow $\mathrm{s}$ milk was ex- 
plored. The results are given in Tab. 1. The final percentage $(31.1-37.7 \%)$ of animals in whose milk or whey the BLV antibodies were found. exceeded only slightly the values obtained by hematological examination. The sensitivity of the ID test in the determination of BLV antibodies in milk was so low that its use in EBL eradication scheme is out of question.

Table 1

Results of RLV antibody determination in milk using the immunodiffusion test (ID)

\begin{tabular}{|c|c|c|c|c|c|}
\hline $\begin{array}{c}\text { Number } \\
\text { animals } \\
\text { examined }\end{array}$ & $\begin{array}{l}\quad \text { M e } \\
\text { PsNT } \\
\text { serum }\end{array}$ & $\begin{array}{l}d \quad o \\
\text { ID } \\
\text { serum }\end{array}$ & $\begin{array}{l}\text { a m } \\
\text { ID } \\
\text { fresh } \\
\text { milk }\end{array}$ & $\begin{array}{l}t \text { i o } n \\
\text { ID } \\
\text { whey } \\
\text { (chem } \\
\text { rennet) }\end{array}$ & $\begin{array}{c}\text { ID } \\
\text { whey } \\
\text { natural }\end{array}$ \\
\hline 45 & 45 & 45 & 17 & 14 & 15 \\
\hline $100 \%$ & $100 \%$ & $100 \%$ & $37.7 \%$ & $31.1 \%$ & $33.3 \%$ \\
\hline
\end{tabular}

PsNT - Pseudotype neutralization test

We therefore examined the same animals using the ELISA test. The results are given in Table 2 and in Fig. 1 and 2 . The results indicate a statistically significant correlation between the titre of BLV antibodies in milk and serum in the group of cows with normal lactation only. This

Table 2

Results of the BLV antibody determination

in milk using the ELISA test

$n-45$

\begin{tabular}{ccccc} 
ELISA & ELISA & Average & titer & $\begin{array}{c}\text { Correlation } \\
+\end{array}$ \\
\hline & log. & linear & coefficient
\end{tabular}

$\begin{array}{clcccc}\text { serum } & 45 & 0 & 2.84 \pm 0.42 & \doteq 700 \pm 103 & \\ \text { milk } & 45 & 0 & 1.71 \pm 0.86 & \doteq 52 \pm 26 & 0.15 \\ \mathrm{n}-35 & \text { till the culling of dry or with colostrum dairy cows } \\ \text { serum } & 34 & 0 & 2.71 \pm 0.40 & \doteq 520 \pm 76 & \\ \text { milk } & 34 & 0 & 1.32 \pm 0.53 & \doteq 21 \pm 8 & 0.57\end{array}$




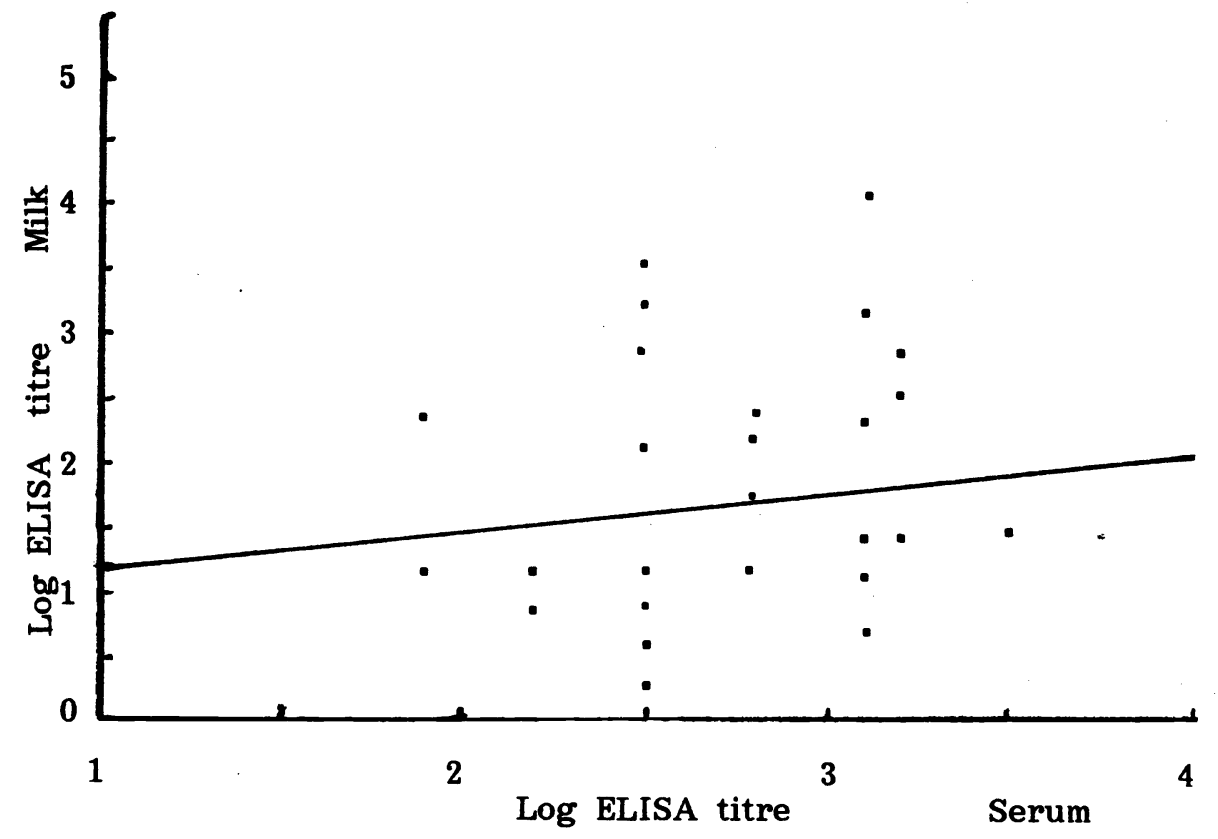

Fig. 1. Correlation between ELISA titres of the BLV antibodies in serum and milk of dairy cows (the entire group) infected with enzootic bovine leukosis

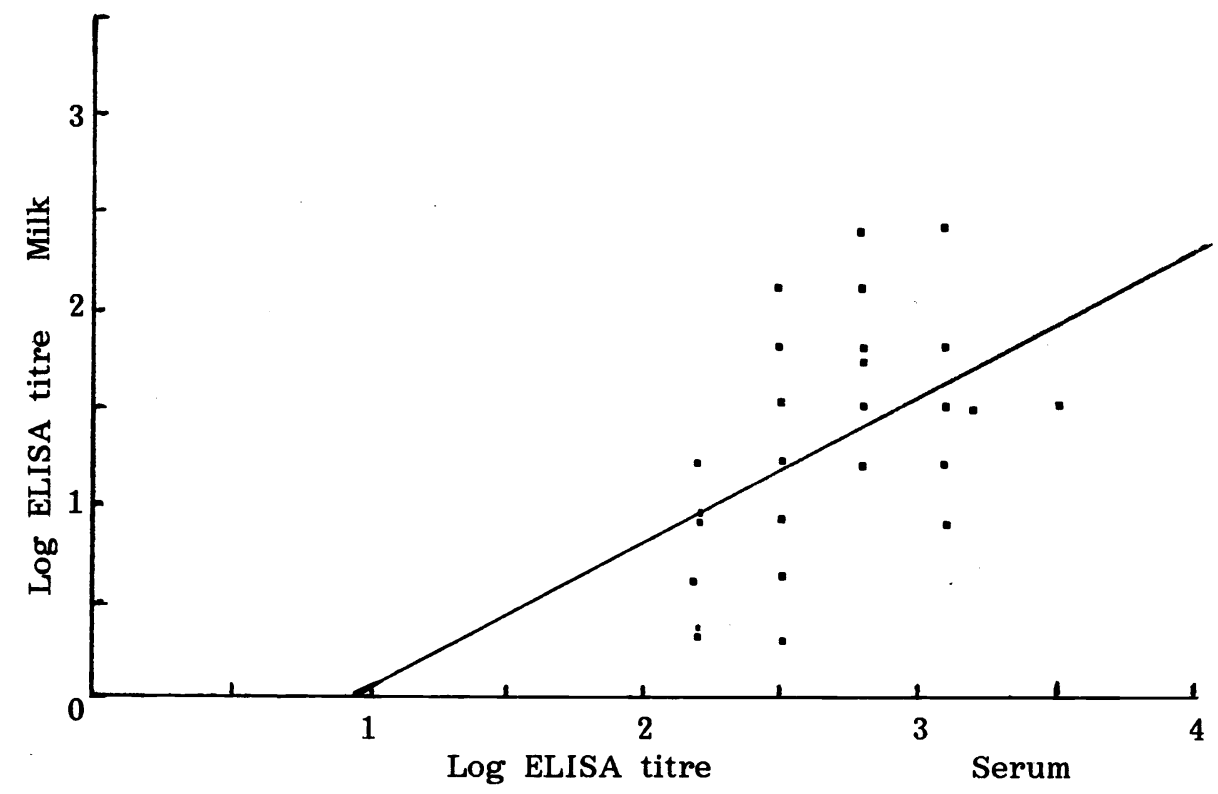

Fig. 2. Correlation between ELISA titres of the BLV antibodies in serum and milk of lactating dairy cows infected with enzootic bovine leukosis 
correlation was not significant when the entire group of animals was evaluated with cows producing colostrum or dry cows included. In the periparturient period the titre of BLV antibodies in the secretion of the mammary gland increased considerably (Fig. 1 and 2). Our results further indicate that the ELISA method sensitivity is so high that using milk, where the antibody concentration is 13-25 times lower than in serum, all serologically positive animals out of 45 dairy cows were detected. The serum antibody titre found in positive animals, demonstrated also by the PsNT test, ranged from 80 to 3200 . In milk, this value was within the interval 2 to 256, and higher titres (up to 3200) were found only in dry cows yielding usually but few $\mathrm{ml}$ of secretion.

In Tables 3 and 4 the results of the positivity of the ID test in dependence on the titre of antibodies to BLV in serum and milk found by the ELISA method are shown. They suggest that this method is by $20 \%$ and $63 \%$ more sensitive in serum and milk, respectively, when compared with the ID test, the sensitivity of which decreased with dropping titre of the antibodies to BLV as detected by the ELISA test.

In the third part of our work, repeated examinations of the experimental animals were carried out. The results of this experiment are in part presented in Tables 5 and 6 showing the results of ELISA tests in serum and milk

Table 3

Serum antibody titre detected by the ELISA method

method compared to the results obtained by the immunodiffusion test

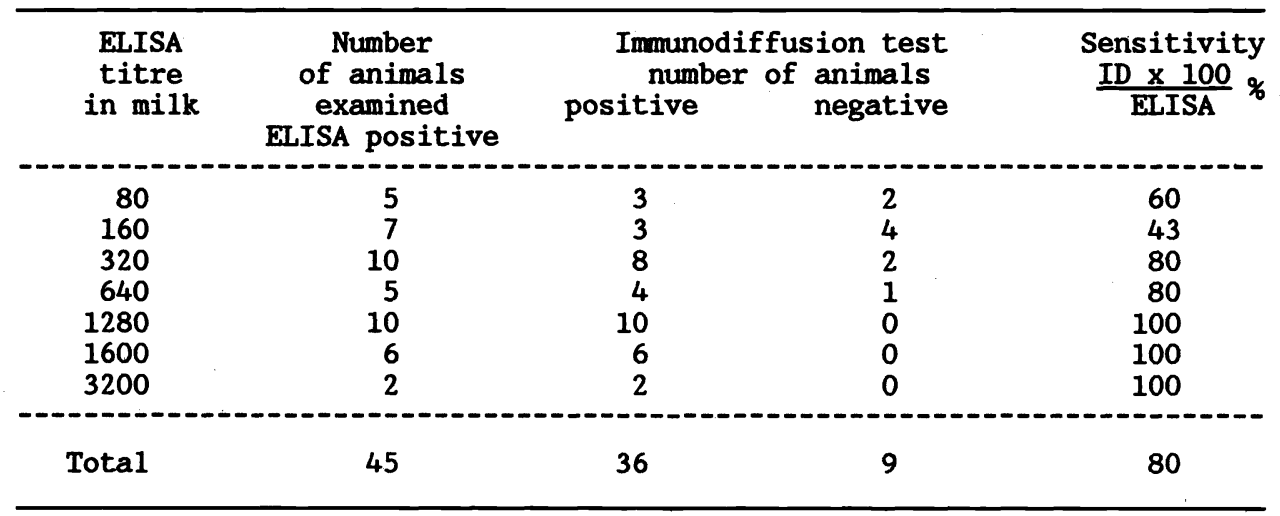


Table 4

Milk antibody titre detected by the ELISA method compared to the results obtained by the immunodiffusion test

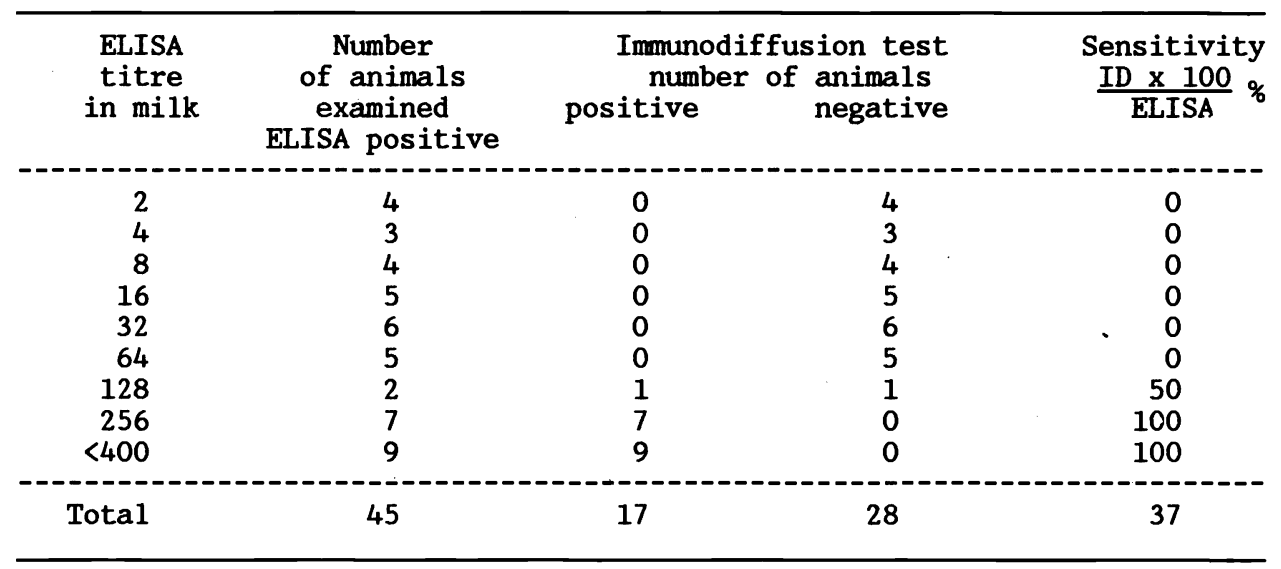

in cows naturally infected and having antibodies against BLV. However, the titre of BLV antibodies in their serum and milk underwent a certain fluctuation. Some animals had a high antibody titre (cow No.4) whereas some had a relatively lower titre (cow No.2). It was also found that in animals at the end of lactation or at the onset of dry period the titre of BLV antibodies increased in milk or milk secretion, and persisted at higher concentration for 2-3 days after parturition (cows No.9 and 13). However, in serum of these animals a decrease in antibody titre occurred. At very low serum titres the BLV antibodies in milk (cow No.6) were not always demonstrated at repeated examinations. From Table 6 it is evident that in serum the antibody titre ranged mostly between 160 and 1280 , the findings in milk being somewhat different. The positive titre of BLV antibodies of lactating cows were within the range of $2-128$, with the frequency peak between 16 and 32 whereas in dry cows or those immediately after parturition the titres were very high $(3200-12800)$.

Further results are shown in Table 7 , giving a survey of titres of BLV antibodies found in experimentally infected cows. They were obtained by repeated examinations of serum and milk. In experimentally infected cows the increased antibody titre was found already on days 13-27 after infection, the ELISA titre ranging from 80 to 640. At the same time, the positivity was also demonstrated by the 


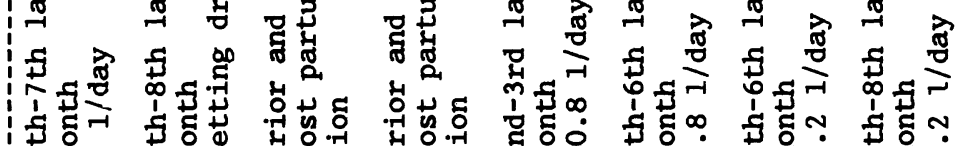

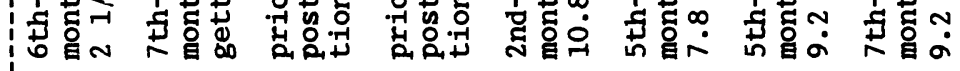
5

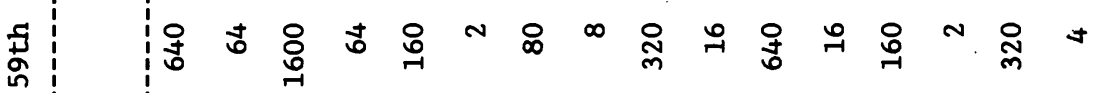
递祡 - 4

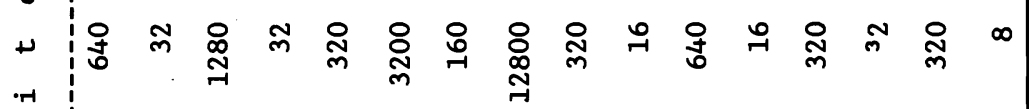
$+$

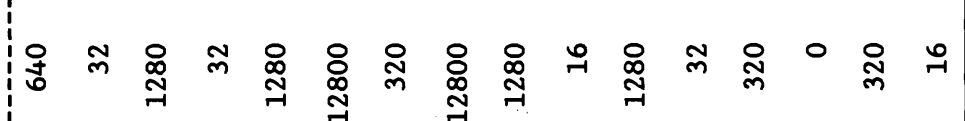

政霉

๑.न

岁总

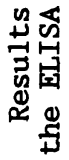

3

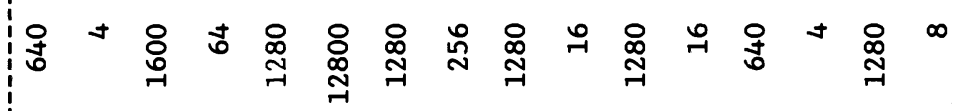
庐

苛

点 $\mapsto$

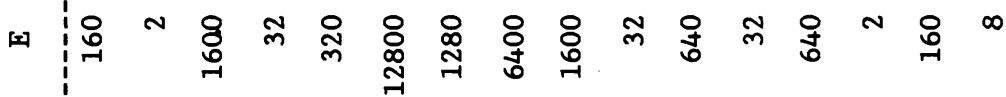

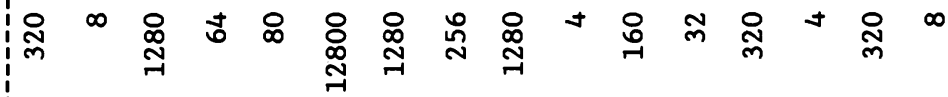
$\sqrt[n]{-1}$

ई

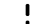

on:

岳

舄 曾

喜 兰

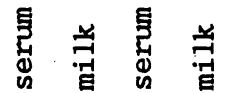

惯

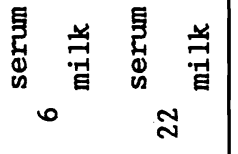




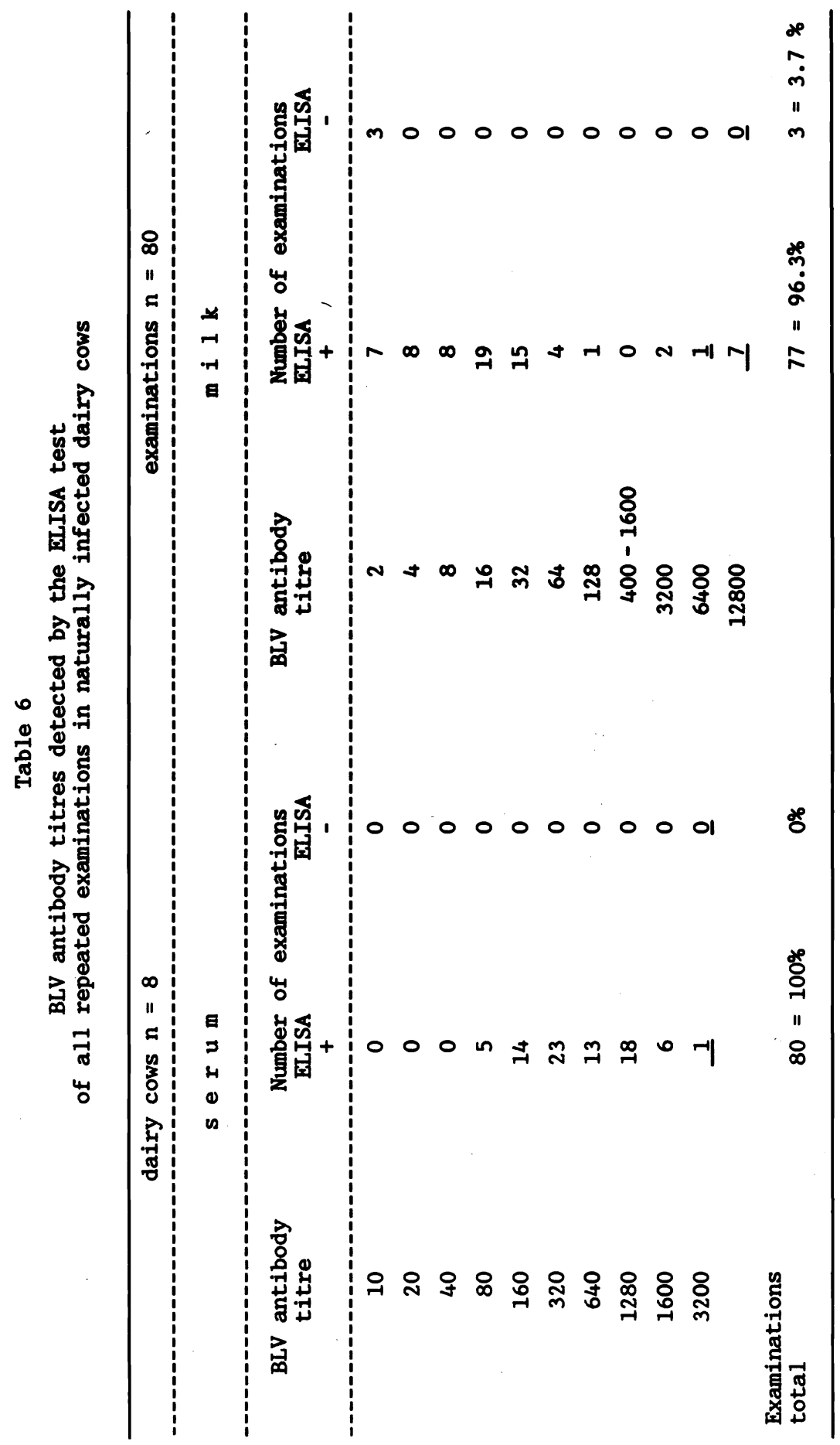




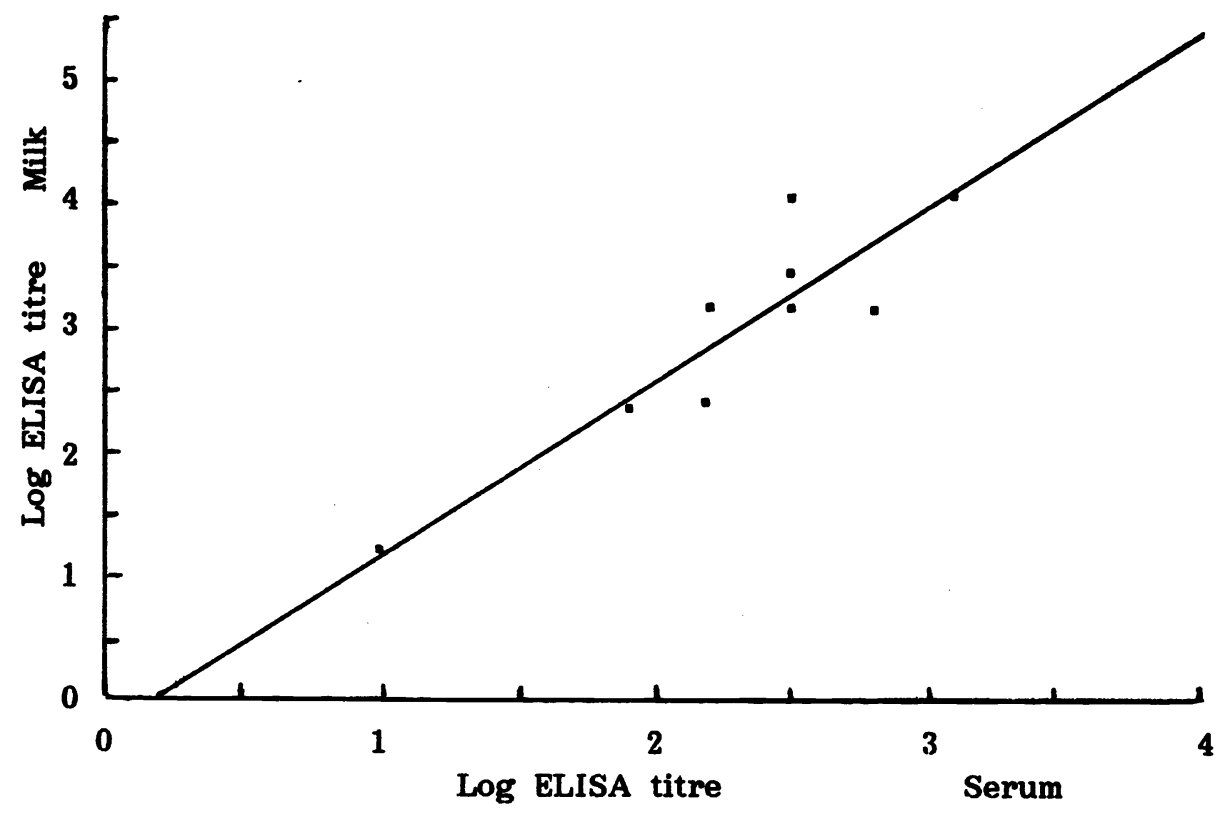

Fig. 3. Correlation between ELISA titres of the BLV antibodies in serum and milk of dry dairy cows only infected with enzootic bovine leukosis

serum neutralization test. In milk, the appeareance of BLV antibodies was slightly delayed as against the serum titres. In cow No. 3, having a relatively high titre in serum and milk, the difference in their appearance was 14 days, in cow No. 10 as many as 40 days. In cow No. 18 the difference was 14 or 40 days since no antibodies were found at each examination (on day 55 post infection no antibodies in milk were found). In this experiment, serologically negative cows, being in contact with the experimentally infected ones were also examined. In cow No. 11, no BLV antibodies were found on repeated examination of milk and serum. In two other animals (No. 14 and 17) higher titres of BLV antibodies were observed on days 13 and 27 after inoculation with the EBL virus. Their appearance was, however, transient, since no titres were detected later and their magnitude of 40 and 80 could not be regarded with certainty as demonstration of EBL infection. Relatively high titre of BLV antibodies was, however, observed in milk beginning day 13 after contact with experimentally infected cows. These animals were in dry period. There 


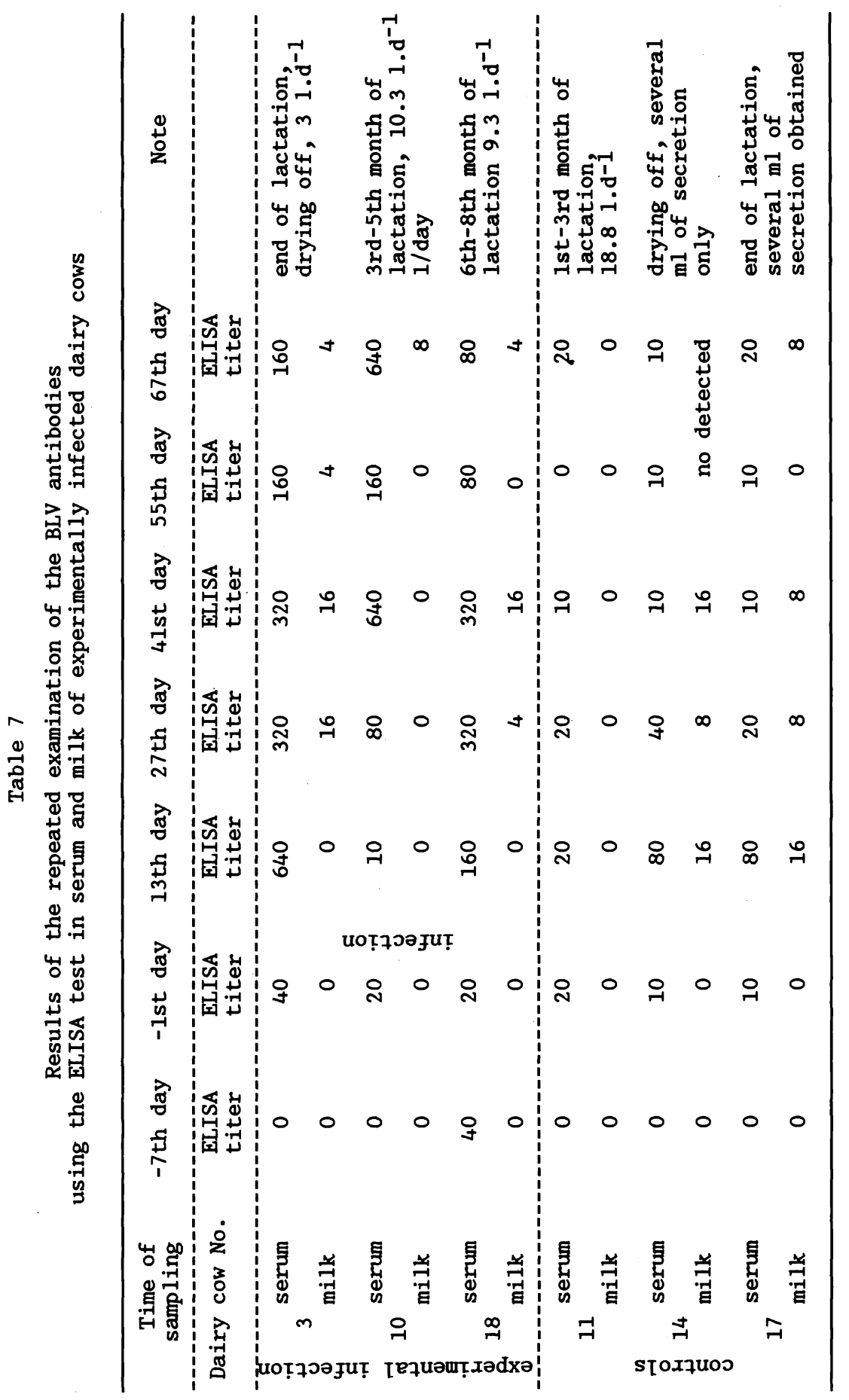


are two explanations possible: in the first case, a specific reaction to contact with BLV can be considered. The ELISA method, due to its high sensitivity, enabled a very early detection of antibodies. They were also found in milk since the animals under study were dry and a high titre of antibodies is usually found in dry cows. On the other hand, a nonspecific reaction should also be considered. This is supported by the fact that particularly in serum antibodies can be demonstrated for a limited period of time and that in no case antibodies were detected by the serum neutralization test.

\section{Discussion}

Comparative studies on serologically defined animals have shown that the sensitivity of the ID test employed for detection of BLV antibodies in milk is very low, and that its use in eradication programs is not suitable. We further proved that reliability of the ELISA test for this purpose is very high. In a group of 45 dairy cows in which antibodies to BLV were found in serum both by serum neutralization and ELISA tests, positive reaction in milk was demonstrated by the ELISA test in all animals examined. We thus confirmed the results obtained by others ( $B$ a $n$ et al. 1982; Z a j a c et al. 1984; E 1 o i t et al. 1987).

Some of the selected cows were followed at weekly intervals over a long period. In periparturient period, the titre of BLV antibodies in their blood serum decreased as reported by other authors ( $\mathrm{T}$ o $\mathrm{m} \mathrm{a}$ et al. 1984). Our research completed these findings by the observation of the antibody titre in the mammary gland secretion rising significantly in the dry period. This increase persisted also after parturition (Table 5). A significant correlation was found between the antibody titre in serum and milk in lactating cows (Fig. 2), except for the dry and colostrum-producing ones (Fig. 1). No such relationship was therefore found for the two last-mentioned groups (Fig. 3) since higher titres were often found in their milk secretion as against their blood serum. The fact that in one out of 8 cows very low titres of BLV antibodies were demonstrated cannot, however, be neglected. We failed to confirm these low titres by repeated examination so that in three out of ten repeated examinations the animal was declared negative. The reliability of BLV antibodies detection in milk in repeated examinations 
reached $96.3 \%$, the erroneous results in comparison with serum were $3.7 \%$. This value corresponds closely to that of $\mathrm{T} \circ \mathrm{m} \mathrm{a}$ et al. (1984) who reported $4.1 \%$ of erroneous results in milk, drawing attention to the fact that these values may be due to the low titre of antibodies in dairy cow ${ }^{-}$s milk. This substantially lower titre of BLV antibodies in milk as compared with that in blood serum may also account for the fact that the antibody occurrence in milk is delayed as against serum by 14 to 28 days (Table 7). This was shown in our experimentally infected animals. It is likely that in natural infection this difference would be even larger.

The ID test was shown to be unsuitable for BLV antibodies in cow's milk. In conclusion, detection of antibodies to BLV in milk by the ELISA method seems to be a suitable screening method for the EBL eradication programs. Using this method in serologically defined animals, 96.3 to $100 \%$ of positive animals were identified.

\section{Průkaz protilátek proti enzootické bovinní leukóze v mléce dojnic ELISA testem}

Byla studována moźnost detekce anti-BLV protilátek v mléce dojnic ELISA a imunodifuzním testem. Výsledky ukázaly, že citlivost imunodifuzního testu při zjištování anti-BLV protilátek $v$ mléce je nízká. Při použití této metody byly protilátky $v$ mléce prokázány pouze $u 37,7 \%$ dojnic $\mathrm{z}$ těch, u kterých byly prokázány $v$ séru. Ve stejných podmínkách provedená vyšetření ELISA testem dala shodné výsledky (sérum - mléko) v 96,3 - 100,0\%. Byla prokázána vysoká korelace mezi titrem protilátek $\mathrm{v}$ séru a mléce. Titr protilátek $\mathrm{v}$ mléce ve srovnání se sérem při provedení ELISA metodou je až 25x nižší. Průkaz anti-BLV protilátek $v$ mléce dojnic je vhodný způsob $\mathrm{k}$ detekci enzootické leukózy skotu ve stádě.

Применение молока дойных коров для определения антител против Энзоотического лейкоза крупного рогатого скота ЭЛИЗА тестом

Изучались возможности определения антител против лейкоза крупного рогатого скота в молоке дойных 
коров ЭЛИЗА и иммунодиФФузным тестами. По полученным результатам было установлено, что чувствительность иммунодифФузного теста к определению антител энзоотического лейкоза в молоке низкая. При использовании данного метода антитела были в молоке обнаружены лишь у 37,7 \% дойных коров из тех, y которых они были детектированы в сыворотке. При одинаковых условиях проводили исследования ЭЛизА тестом с тождественными результатами (сыворотка - молоко) 96,3 - 100,0 \%. Была установлена высокая корреляция между титром антител в сыворотке и молоке. Титр антител в молоке по сравнению с сывороткой при исследовании методом ЭлизА в 25 раз ниже. Определение антител против энзоотического лейкоза в молоке дойных коров является пригодным способом детектирования энзоотического лейкоза крупного рогатого скота в стаде.

\section{References}

ALTANER, C. - ZAJAC, V. - ČERNÝ, L.: Nové přístupy k rychlé a hromadné diagnostice bovinni leukózy. Veterinářstvi, 32, 1982, 389 - 391.

BÁN, J. - ZAJAC, V. - ALTANER, C. - ČERNÝ, L.: Early diagnosis of virus induced bovine leukosis in milk - a simple modified ELISA test. Zb1. Vet. Med. B., 29, 1982, 591 - 594 .

BENDA, I.: Program tlumeni enzootické leukózy skotu v ČSR. I. veterinárske onkologické dni (Abstracts of Papers), Košice, ÚEVM, 1984, 52 - 54.

ELOIT, M. - VUILLAUME, A. - DURET, C. - PRÉVOST, P. - TOMA, B.: Etude de 1 evolution des anticorps de la leucose bovine enzootique dans le lait au cours de la lactation. Rec. Méd. Vét., 163, 1987, 555 - 560.

FERRER, J. F. - DIGLIO, C. A.: Development of an in vitro infectivity assay for the C-type bovine leukemia virus. Canc. Res., 36, 1976, 1068 - 1073.

FRANZ, J. - SVOBODA, I. - HAMPL, J. - GRANÁTOVÁ, M. - MÁDR, V. - KOZÁKOVÁ, A. - MACHATKOVÁ, M. - HOFIREK, B. - JAGOS, P. - DEDEK, L. - MACURA, B.: Diagnosis of bovine leukemia. Project report, Brno, VUVeL, 1948, $38 \mathrm{p}$.

HOFIREK, B. - KABELIK, V. - FRANZ, J. - GRANÁTOVÁ, M. - SVOBODA, I. - HOJOVCOVÁ, M. - DACIK, F. - PANTÓCEK, B.: Výsledky použití sérologických metod pr̆i tlumeni enzootické leukózy skotu ve velkochovech. Veterinár̆stvi, 35, 1985, 103 - 105.

TOMA, B. - VUILLAUME, A. - MANET, G. - DURET, CH. - ELOIT, M. - CRESPEAU, F. - CHAPPUIS, G. - PARODI, A.: Dépistage de la leucose bovine enzootique par application du test ELISA sur le lait. Rec. Méd. Vét., 160, 1984, $53-60$.

ZAJAC, V. - BÁN, J. - ALTANER, C. - ČERNÝ, L.: Metódy včasnej diagnostiky leukózy $u$ hovädzieho dobytka. I. veterinárske onkologické dni. Abstracts of Papers. Košice, ÚEVM, 1984: 59 - 61. 
ZÁVADA, J. - ČERNÝ, L. - ALTSTEIN, A. - ZÁVADOVÁ, Z.: Pseudotype particles of vesicular stomatitis virus surface antigens of bovine leukaemia virus - VSV/BLV/ as sensitive probe for detecting antibodies in the sera of spontaneously infected cattle. Acta Virol., 22, 1978, $91-96$. 